\title{
PENERAPAN MODEL PEMBELAJARAN BERBASIS LINGKUNGAN DALAM UPAYA MENINGKATKAN KETERAMPILAN PROSES SAINS SISWA SMA METRO
}

\author{
Mia Cholvistaria \\ Pendidikan Biologi FKIP Universitas Muhammadiyah Metro \\ E-mail: miacholvis@yahoo.co.id
}

\begin{abstract}
The aims of the study was to apply the environment based learning model in an effort to improve students' science process skills. The research was conducted by the classroom action research on class X2 SMAN 2 Metro academic year 2011/2012 indicated that students' science process skills still have not shown good results. Because the achievement still under $50 \%$ with the percentage of students who reach the KKM ( $\geq 70 \%$ ). The curriculum is currently implemented of KTSP where the teachers are required to be able to manage with the student centered learning. One model of learning which are student centered learning is environment based learning model. The results show that the science process skills increase from $50.00 \%$ to $79.45 \%$ increase of $29.45 \%$. Based on the results of research can be concluded that the study uses a model-based learning environment can improve the skills sains process.
\end{abstract}

Kata kunci: Pembelajaran Berbasis Lingkungan, Keterampilan Proses Sains

Kurikulum yang berlaku saat ini adalah Kurikulum Tingkat Satuan Pendidikan (KTSP), dimana kurikulum ini menuntut kreativitas seorang guru dalam mengelola proses pembelajaran yang berpusat pada peserta didik. Biologi sebagai salah satu mata pelajaran IPA yang memiliki banyak materi yang bersifat abstrak dan sulit untuk dimengerti serta materi biologi banyak tersedia pada lingkungan sekitar. Oleh karena itu diperlukanlah sebuah model pembelajaran yang mampu membantu seorang guru untuk menjelaskan materi tersebut, salah satu model pembelajaran yang dapat digunakan untuk membantu seorang guru menyampaikan materimateri serta dapat memanfaatkan apa yang disediakan oleh alam adalah model pembelajaran berbasis lingkungan, yang merupakan hasil dampak positif dari kegiatan pemanfaatan lingkungan untuk digunakan dengan tujuan mengembangkan keterampilan proses sains dan hasil belajar siswa karena dapat menciptakan suasana pembelajaran yang lebih menarik, lebih menyenangkan, lebih interaktif, tidak membosankan, serta efektif dan efesien.

Dalam peningkatan keterampilan proses, penggunaan model pembelajaran akan merangsang siswa dan berbagai kemampuan siswa dalam pembelajaran, karena penggunaan model pembelajaran yang tepat akan meningkatkan kemampuan siswa. Oleh karena itu peneliti mencoba menggunakan model pembelajaran berbasis lingkungan dalam upaya meningkatkan keterampilan proses sains dan hasil belajar siswa 
biologi kelas $\mathrm{X}_{2}$ SMA Negeri 2 Metro tahun pelajaran 2011/2012. Terdapat beberapa faktor yang mempengaruhi hasil belajar siswa dan pembelajaran yaitu faktor internal yang diklasifikasikan menjadi dua yang pertama faktor fisiologis dan kedua faktor psikologis berupa inteligensi, emosi, bakat, motivasi dan perhatian. Selain faktor internal, faktor yang datangnya dari luar juga ikut berpengaruh yaitu faktor eksternal adalah segala sesuatu yang berada di luar diri individu atau sering disebut dengan lingkungan. Pendidikan IPA juga diarahkan untuk mencari tahu dan berbuat sehingga dapat membantu peserta didik dalam memperoleh pemahaman yang lebih mendalam tentang dirinya sendiri dan alam sekitar. Biologi sebagai salah satu ilmu sains yang menyediakan pengalaman belajar untuk memahami konsep dan keterampilan proses sains.

Hal ini berarti, pembelajaran biologi semestinya dapat digunakan untuk membentuk kemampuan yang utuh, dalam arti mempunyai sikap, kemampuan kognitif, dan keterampilan memecahkan masalah yang dihadapi. Dalam penelitian ini lingkungan merupakan salah satu sumber belajar yang amat penting dan memiliki nilainilai yang sangat berharga dalam rangka proses pembelajaran siswa. Penggunaaan lingkungan memungkinkan terjadinya proses belajar yang lebih bermakna sebab anak dihadapkan pada kondisi yang sebenarnya. Dengan memanfaatkan lingkungan sebagai media pembelajaran diharapkan siswa mampu mengembangkan serta melestarikan sumber daya alam dan meningkatkan kualitas sumber daya manusia (Setiawan:2011). Dari beberapa faktor dan latarbelakang masalah di atas dalam menciptakan suasana pembelajaran yang efektif, eisien dan tidak membosankan peneliti memilih model pembelajaran berbasis lingkungan untuk meningkatkan hasil belajar siswa dan meningkatkan keterampilan proses sains dalam kegiatan pembelajaran.

\section{METODE}

Penelitian ini dilaksanakan di SMA Negeri 2 METRO pada senester genap T.P 2011/2012 yakni bulan Januari sampai Februari 2012. Subjek penelitian ini adalah siswa kelas $\mathrm{X}_{2}$. Objek penelitiannya adalah pembelajaran Biologi yang dtitik beratkan pada penggunaan model pembelajaran berbasis lingkungan. materi penelitian yang dilaksanakan untuk standar kompetensi, yaitu memahami manfaat keanekaragaman hayati. Sedangkan kompetensi dasar yang dijadikan kajian penelitian, adalah mendeskripsikan konsep keanekaragaman gen, jenis, ekosistem, melalui kegiatan pengamatan. Data yang diambil berupa kualitas pembelajaran yaikni keterampilan proses sains siswa. Pengumpulan data dilakukan observasi atau penceklisan keterampilan proses sains pada lembar pengamatan yang telah didesains sebelumnya, pengambilan data dilaksanakan selama kegiatan pembelajaran berlangsung. Analisa data dihitung secara kuantitatif. Pelaksanaan pembelajaran dilakukan dalam dua siklus yang meliputi kegiatan perencanaan, observasi dan evalusi serta analisa dan refleksi, mengikuti model Mc Kernen. 
HASIL

\section{Siklus I}

Berdasarkan hasil observasi aktivitas keterampilan proses sains siswa selama proses pembelajaran berlangsung menunjukkan bahwa pada pertemuan pertama siswa yang melakukan KP్ㅛ 70\% sebanyak 16 siswa atau 53,33\%, pertemuan kedua siswa yang melakukan KPS $\geq 70 \%$ sebanyak 17 siswa atau 53,12\%. Pada pertemuan pertama tidak banyak siswa yang melakukan KPS dengan semua indikator yang diamati dikarnakan siswa masih dalam tahap penyesuaian KPS yang diadakan dalam kegiatan pembelajaran, karena sesungguhnya keterampilan proses sains adalah kegiatan yang sering kita lakukan dalam kegiatan praktikum di Labolatorium. Pada pertemuan kedua persentase sedikit meningkat hal ini disebabkan karena siswa sudah mulai menyadari pentingnya KPS dalam melakukan kegiatan pembelajaran dimana KPS akan membantu siswa lebih mandiri dan aktif. Rata-rata persentase KPS siswa yang melakukan KPS $\geq 70 \%$ adalah 53,23\%, sedangkan siswa yang kurang aktif adalah 43,33\%. Berdasarkan data tersebut, jumlah siswa yang aktif tidak banyak meningkat dibandingkan dengan siswa yang kurang aktif. Peningkatan persentase mencapai $10 \%$ dilihat dari banyak siswa yang melakukan aktivitas dan jumlah siswa yang hadir dalam kegiatan pembelajaran.
Hasil observasi aktivitas pada siklus I dapat dinyatakan dalam bentuk persentase pada Tabel 1.

\section{Siklus II}

Berdasarkan hasil observasi aktivitas KPS siswa selama proses pembelajaran berlangsung menunjukkan bahwa pada pertemuan pertama siswa yang melakukan KPS $\geq 70 \%$ sebanyak 22 siswa atau 81,48\%, pertamuan kedua siswa yang melakukan KPS 70\% sebanyak 24 siswa atau 77,41 \%. KPS siswa pada siklus II dalam kegiatan pembelajaran meningkat hingga mencapai 26,22\%, dan rata-rata persentase KPS siswa yang melakukan KPS $\geq 70 \%$ adalah $68,33 \%$, sedangkan rata-rata persentasi siswa yang kurang aktif adalah 25\%. Berdasarkan data tersebut, jumlah siswa yang aktif lebih banyak dibandingkan dengan siswa yang kurang aktif. Pada siklus II ini persentase siswa yang melakukan KPS70\% sudah mencapai indikator keberhasilan pembelajaran yaitu $\geq 75 \%$. Peningkatan mencapai 20\% dilihat dari banyak siswa yang melakukan aktivitas dan banyaknya jumlah siswa yang hadir dalam kegiatan pembelajaran. Persentase terlihat menurun yang sebenarnya adalah meningkat dikarnakan jumlah siswa yang hadir lebih sedikit dibandingkan jumlah siswa pada pertemuan kedua. Pada pertemuan pertama siswa yang tidak hadir berjumlah 5 siswa sedangkan pada siswa yang tidak hadir dipertemuan kedua hanya 1 siswa. Hal ini yang menyebabkan persentase menjadi terlihat tidak mengalami peningkatan. 
Tabel 1. Persentase KPS Siswa yang melakukan aktivitas $\geq 70 \%$

\begin{tabular}{|c|c|c|c|c|c|}
\hline \multirow{2}{*}{ Siklus } & \multicolumn{4}{|c|}{ Pertemuan } & \multirow{2}{*}{ Keterangan } \\
\hline & \multicolumn{2}{|c|}{ I } & \multicolumn{2}{|c|}{ II } & \\
\hline & Jumlah siswa & $\%$ & Jumlah siswa & $\%$ & Dari pertemuan \\
\hline I & $\begin{array}{l}16 \text { Siswa } \\
(\mathrm{n}=30)\end{array}$ & $53,33 \%$ & $\begin{array}{l}17 \text { Siswa } \\
(\mathrm{n}=32)\end{array}$ & $53,12 \%$ & $\begin{array}{l}\text { dengan pertemuan } \\
\text { medua KPS } \\
\text { pengalami } \\
\text { dilihat dari jumlah } \\
\text { siswa yang hadir dan } \\
\text { aktivitasnya. }\end{array}$ \\
\hline
\end{tabular}

Tabel 2. Persentase KPS Siswa yang melakukan aktivitas $\geq 70 \%$

\begin{tabular}{|c|c|c|c|c|c|}
\hline \multirow{2}{*}{ Siklus } & \multicolumn{4}{|c|}{ Pertemuan } & \multirow{2}{*}{ Keterangan } \\
\hline & \multicolumn{2}{|c|}{ I } & \multicolumn{2}{|c|}{ II } & \\
\hline & $\begin{array}{c}\text { Jumlah } \\
\text { siswa }\end{array}$ & $\%$ & $\begin{array}{c}\text { Jumlah } \\
\text { siswa }\end{array}$ & $\%$ & \multirow{2}{*}{$\begin{array}{l}\text { Dari pertemuan pertama } \\
\text { sampai dengan pertemuan } \\
\text { kedua KPS mengalami } \\
\text { peningkatan } 6,45 \% \text { dilihat } \\
\text { dari jumlah siswa yang } \\
\text { hadir dan aktivitasnya. }\end{array}$} \\
\hline II & $\begin{array}{l}22 \text { Siswa } \\
(\mathrm{n}=27)\end{array}$ & $81,48 \%$ & $\begin{array}{l}24 \text { Siswa } \\
\quad(n=31)\end{array}$ & $77,41 \%$ & \\
\hline
\end{tabular}

Siswa sudah terbiasa melakukan aktivitas-aktivitas belajar, sehingga rasa takut untuk bertanya, takut menjawab pertanyaan atau memberikan tanggapan terhadap pertanyaan dari temannya dalam proses diskusi sudah sedikit berkurang, dalam melakukan pengamatan siswa sudah mulai menerapkan keterampilan proses sains sehingga dalam mengidentifikasi siswa sudah fokus dengan apa yang akan diamati, mencari jawaban sendiri atas tujuan pembelajaran dan masalah yang sedang dipecahkan. Hasil observasi aktivitas pada siklus II dapat dinyatakan dalam bentuk persentase pada Tabel 2 .

\section{PEMBAHASAN}

Berdasarkan hasil penelitian yang telah diuraikan di atas, maka diperoleh gambaran tentang pembelajaran dengan menggunakan model pembelajaran berbasis lingkungan dalam meningkatkan keterampilan proses sains dan hasil belajar siswa pada materi pokok semester genap yaitu keanekaragaman hayati yang diuraikan dalam empat kali pertemuan dengan submateri keanekaragaman tingkat gen, keanekaragaman tingkat jenis, klasifikasi dan keanekaragaman tingkat ekosistem, dalam dua siklus pada Gambar 1.

Untuk hasil pembelajaran yang optimal dalam proses pembelajaran salah satu faktor yang perlu dipertimbangkan 
adalah penggunaan model pembelajaran yang tepat yang disesuaikan dengan materi pelajaran dan tujuan pembelajaran yang hendak dicapai. Berdasarkan penelitian yang dilakukan di kelas $\mathrm{X}_{2}$ SMA Negeri 2 Metro semester genap tahun pelajaran 2011/2012, penggunaan model pembelajaran berbasis lingkungan dalam pembelajaran dapat meningkatkan keterampilan proses sains dan hasil belajar siswa. Dengan melihat langkahlangkah pembelajaran dengan menggunakan model pembelajaran berbasis lingkungan, maka Penggunaan model pembelajaran ini dalam proses pembelajaran akan selalu menghadapkan siswa pada objek dan permasalahannya langsung. Dengan demikian siswa mempunyai kesempatan untuk menata sendiri dan memencari jawabannya langsung dalam penerapan keterampilan proses sains siswa dengan menggunakan beberapa indra, pengamatan langsung menjadi satu kesatuan yang bermakna sehingga hal yang siswa terima dapat tersimpan dengan baik dan tahan lama serta pembelajaran menjadi lebih bermakna (Setiawan, 2011).

Penggunaan model pembelajaran berbasis lingkungan akan menjadikan interaksi belajar lebih terbangun, baik interaksi antara siswa dengan siswa, maupun antara siswa dengan guru. Hal ini terjadi karena selama proses pembelajaran siswa dituntut untuk selalu aktif dalam kelompoknya masingmasing. Dengan demikian siswa dapat menanyakan dan meminta penjelasan mengenai yang tidak diketahuinya kepada teman sekelompok ataupun kepada guru. Disamping itu, guru harus senantiasa siap membimbing siswa dalam kegiatan pengamatan, memberikan petunjuk, keterangan dan motivasi.

Dengan adanya kelebihan dari model pembelajaran berbasis lingkungan yang diterapkan dalam proses pembelajaran, model pembelajaran ini dapat meningkatkan persentase siswa yang aktif dalam aktivitas KPS siswa. Pada aspek mengajukan pertanyaan mengalami kenaikan persentase dari pertemuan pertama sampai pertemuan kedua pada siklus I, sedangkan siklus II dibandingkan dengan persentase pada siklus I mengalami penurunan, tetapi persentase dipertemuan kedua siklus II meningkat dibandingkan dengan pertemuan pertama siklus II walaupun persentase tetap tinggi pada siklus I. Persentase siswa yang aktif pada siklus I dan siklus II mengalami peningkatan, hal ini sesuai dengan pendapat Mulyasa (2009) bahwa pembelajaran berdasarkan pendekatan keterampilan proses hal yang perlu diperhatikan adalah kegiatankegiatan yang dapat dilakukan untuk mendorong aktivitas dan kreaktivitas peserta didik dalam pembelajaran antara lain: diskusi, pengamatan, penelitian, praktikum, tanya jawab, karyawisata, studi kasus, bermain peran, dan kegiatan-kegiatan lain yang dapat menunjang tercapainya tujuan pembelajaran.

Dalam desain pembelajaran berbasis lingkungan didesain dengan dasar pendapat di atas, kegiatan di dalamnya terdapat beberapa kegiatan yang akan memunculkan KPS yaitu pengamatan, diskusi, dan tanya jawab. Hal ini yang menjadi landasan bahwa KPS akan bisa terus meningkat selama kegiatan pembelajaran didesain sesuai kondisi dan tujuan pembelajaran. Hasil penelitian ini menunjukkan bahwa model pembelajaran berbasis lingkungan 
dapat meningkatkan keterampilan proses sains. Siswa yang belajar melalui model pembelajaran berbasis lingkungan memiliki persentase atau sekor nilai yang semakin meningkat. Hasil yang terungkap bahwa kenaikan persentase atau skor KPS tidak dipengaruhi oleh tinggi atau rendahnya nilai akademik siswa, persentase menunjukan bahwa siswa yang memiliki akademik kurang atau memiliki kemampuan di bawah rata-rata dapat melakukan aktivitas KPS tinggi dan mendapat nilai hasil belajar di atas rata-rata nilai KKM dalam evalusi tes akhir siklus. Hal ini sesuai dengan pendapat Muhammad (dalam Trianto, 2010:150) bahwa penerapan keterampilan proses sains dapat meningkatkan motivasi dan hasil belajar siswa, menuntaskan hasil belajar secara serentak, dan menemukan sendiri konsepsi serta dapat mendefinisikan secara benar. Melatihkan keterampilan proses sains merupakan salah satu upaya yang penting untuk memperoleh keberhasilan belajar siswa yang optimal, materi pelajaran akan lebih mudah dipahami, dipelajari, dihayati dan diingat dalam waktu yang relatif lama bila siswa sendiri memperoleh pengalaman langsung dari peristiwa belajar tersebut melalui pengamatan. Keterampilan proses sains dapat mengembangkan pengetahuan teori atau konsep dengan kenyataan dalam kehidupan bermasyarakat. Sehingga siswa yang menerapkan KPS secara terstruktur dapat meningkatkan dan menuntaskan hasil belajar.

Dalam penelitian ini siswa yang memiliki akademik tinggi atau memiliki nilai tinggi di hasil pra PTK ketika diterapkan KPS dengan aktivitas mandiri siswa tersebut mendapatkan hasil belajar yang mengalami penurunan diakhir siklus II. Peneliti melihat bahwa siswa yang memiliki kemampuan di atas ratarata memiliki tingkat emosional yang tinggi merasa benar atas apa yang dilakukannya tidak hanya emosi ketika kegiatan pembelajaran berlangsung yang mempengaruhi naik atau menurunnya hasil belajar siswa tersebut melainkan kondisi psikologis siswa yang tidak siap untuk melakukan evaluasi, hal ini mendukung dari pendapat Rusyan (2008) bahwa Motivasi, kematangan dan kesiapan diperlukan dalam proses pembelajaran, tanpa motivasi dalam proses pembelajaran, terutama motivasi instristik proses pembelajaran tidak akan efektif dan tanpa adanya kesiapan siswa sebelum berlangsungnya pembelajaran dan upaya belajar sukar berlangsung. Berbanding terbalik pada siswa yang pada hasil pra PTK termasuk ke dalam siswa yang memiliki kemampuan kurang aktivitas KPS yang didapat meningkat. Aktivitas KPS yang meningkat dirasakan atas adanya pengelompokan siswa yang bersifat heterogen, di dalam kelompok terjalin kerjasama dan interaksi yang positif dalam kegiatan pembelajaran setiap anggota kelompoknya saling mengajari dan membantu satu sama lain sehingga terjadi proses transfer informasi satu dengan yang lain untuk saling mendukung, selain itu emosional yang dibentuk oleh lingkungan belajar yang menyenangkan menjadi hal penting dalam meningkatkan keterampilan proses sains.

Seperti yang diungkapkan oleh Sagala (2008) Pengajaran dengan alam sekitar atau lingkungan memberikan kesempatan sebanyak-banyaknya agar siswa aktif dan giat, pengajaran alam sekitar memungkinkan untuk memberikan pengajaran totalitas serta memberikan apersepsi emosional pada 
siswa. Hal serupa diungkapkan oleh Hamzah (2011) bahwa konsep pembelajaran dengan menggunakan lingkungan memberikan peluang yang sangat besar kepada peserta didik untuk meningkatkan hasil belajarnya, dan secara umum konsep pembelajaran dengan menggunakan lingkungan dapat meningkatkan motivasi belajar dari peserta didik, sehingga bimbingan dan motivasi guru serta lingkungan berperan penting dalam pembentukan karakter atau sikap siswa termasuk emosional siswa dalam melakukan kegiatan pembelajaran kearah sikap yang lebih baik. Siswa yang aktif terus meningkat. Peningkatan persentase siswa yang aktif diuraikan dalam Tabel 3.

\section{Tabel 3. Data Peningkatan Keterampilan Proses Sains antara Siklus I dengan}

Siklus II

\begin{tabular}{|c|l|c|c|c|}
\hline \multirow{2}{*}{ No. } & \multirow{2}{*}{ Jenis Keterampilan } & \multicolumn{2}{|c|}{ Presentase } & $\begin{array}{c}\text { Peningkatan } \\
\text { Siklus I-Siklus II }\end{array}$ \\
\cline { 3 - 4 } & & Siklus I & Siklus II & \\
\hline 1 & Observasi & $79,23 \%$ & $83,37 \%$ & $4,14 \%$ \\
\hline 2 & Klasifikasi & $72,74 \%$ & $88,23 \%$ & $15,49 \%$ \\
\hline 3 & Komunikasi & $32,03 \%$ & $43,75 \%$ & $11,72 \%$ \\
\hline 4 & Mengajukan pertanyaan & $32,18 \%$ & $34,40 \%$ & $2,22 \%$ \\
\hline 5 & Menyimpulkan & $85,20 \%$ & $87,51 \%$ & $2,31 \%$ \\
\hline
\end{tabular}

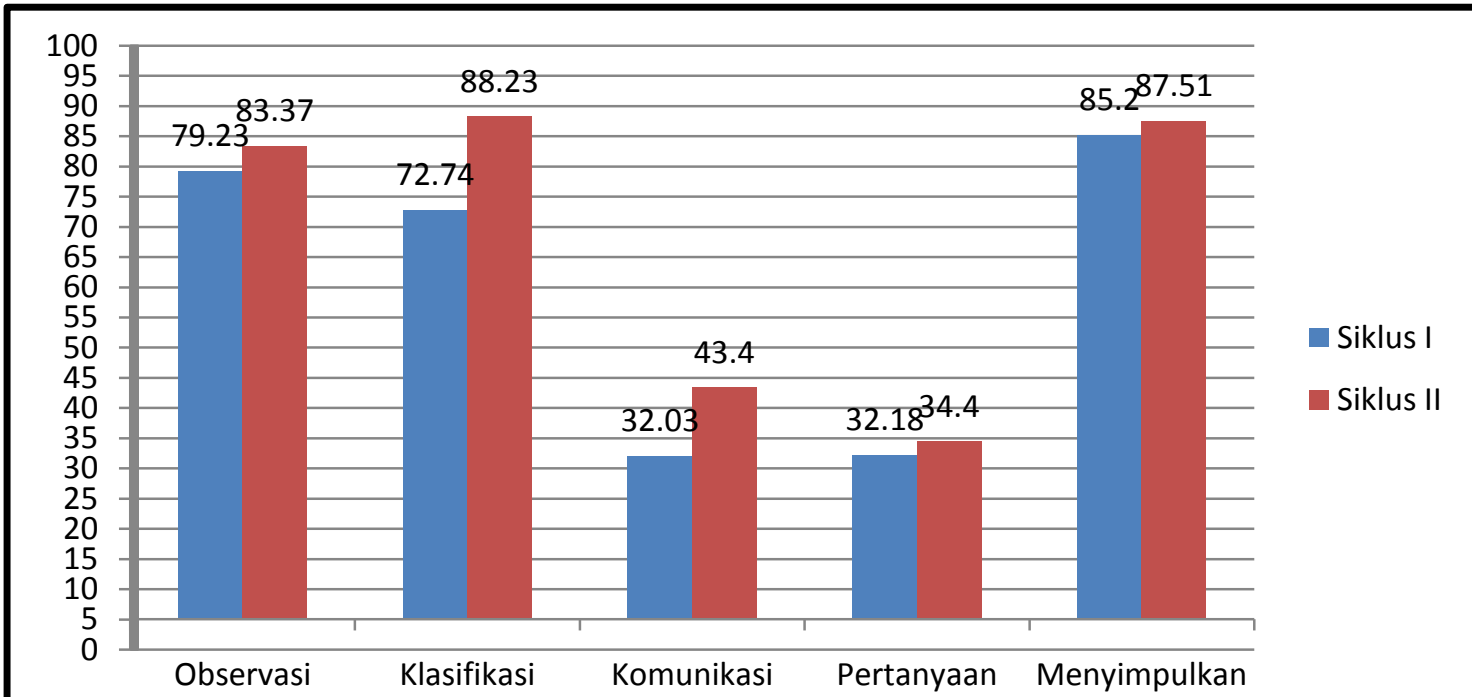

Gambar 1. Peningkatan KPS pada Siklus I dan Siklus II 
Dari Tabel 3 dan Gambar 1 di atas dapat kita lihat peningkatan persentase siswa yang aktif dalam KPS sebagai berikut:

\section{a. Observasi (Pengamatan)}

Untuk KPS observasi atau pengamatan yang terdiri dari 3 indikator yaitu menggunakan indra penglihatan dalam melakukan pengamatan, menggunakan indra perabaan dalam melakukan pengamatan dan menggunakan indra pembau dalam melakukan pangamatan, terlihat persentase siswa yang aktif pada siklus I yaitu pertemuan pertama $85,55 \%$, dan pertemuan kedua mengalami penurunan presentase menjadi $72,91 \%$. Hal ini dikarnakan indikator aktivitas dalam melakukan pengamatan dengan indra pembau mengalami penurunan, persentase yang menurun disebabkan oleh objek yang digunakan tidak banyak mendukung untuk meningkatnya aktivitas ini, objek tersebut adalah daun. Tidak seperti pada objek pertemuan pertama yaitu bunga, bunga adalah hal yang terbiasa untuk aktivitas tersebut. Pada pertemuan pertama siklus II siswa yang aktif mengalami peningkatan dari pertemuan sebelumnya yaitu dari 72,91\% menjadi 83,95\%. Hal ini dikarenakan materi pada pertemuan pertama siklus II masih terkait pada pertemuan sebelumnya sehingga siswa lebih teliti dalam mengidentifikasi dikarnakan pada pertemuan ini identifikasi dan pengelompokan daun dengan menggunakan kunci dikotomis, pengelompokan harus benar-benar terperinci hingga semua daun memiliki perbedaan untuk digolongkan pada karakteristik penggolongan. Sedangkan untuk pertemuan kedua persentase siswa yang aktif menurun menjadi 82,79\%, dan rata-rata persentase siswa yang aktif sebesar 83,37\%. Dengan demikian ratarata persentase siswa dari siklus I ke siklus II mengalami peningkatan sebesar 4,14\%. Kenaikan disebabkan atas bimbingan dan motivasi yang dilakukan kepada siswa sehingga aktivitas yang diharapkan dapat meningkat. Mulyasa (2009:100) mengungkapkan bahwa pendekatan ketrampilan proses bertolak dari suatu pandangan bahwa setiap siswa memiliki potensi yang berbeda, dan dalam situasi normal dengan bimbingan dan motivasi, siswa dapat mengembangkan potensinya secara optimal.

\section{b. Klasifikasi (Pengelompokan)}

Pada KPS dengan aspek klasifikasi yang terdiri dari 3 indikator yaitu mencari persamaan berdasarkan ciri-ciri, mencari perbedaan berdasarkan ciri-ciri dan mencari dasar penggolongan. Persentase siswa yang aktif dari pertemuan pertama pada siklus I sebesar $77,77 \%$ dan pertemuan kedua pada siklus I mengalami penurunan aktivitas Keterampilan proses sains sebesar 67,71\%. Hal ini dikarnakan pada pertemuan pertama aktivitas dengan objek yang digunakan atau yang diamati juga mempengaruhi naik atau turunnya aktivitas setiap indikator keterampialan proses sains, ketika siswa mengamati bunga pada pertemuan pertama siswa lebih mencari persamaan terlebih dahulu kemudian mencari perbedaan dari tiap bunga yang diamati. Sedangkan pada daun siswa lebih ke arah untuk terus mencari perbedaan sehingga aktivitas yang diharapkan tidak sesuai dengan persentasi yang didapat. Hal yang sama terjadi pada siklus II Pertemuan pertama pada siklus II yaitu 92,59\% dan pertemuan kedua mencapai 83,87\%. Selain dari objek yang diamati 
penurunan presentase dikarnakan siswa merasa tidak perlu melakukan indikator ke3 pada aspek KPS klasifikasi yaitu mencari dasar penggolongan karna mencari persamaan dan perbedaan dirasakan cukup dalam mengelompokan suatu objek yang ingin dikelompokan. Hal ini diatasi dengan memberi pemahaman kepada siswa bahwa mencari dasar penggolongan pada suatu objek akan membatu kita mengetahui jawaban dan tujuan pembelajaran. Berkaitan dengan pendapat Trianto (2010:148) bahwa dalam menerapkan keterampilan proses sains memiliki peran yang penting karna penerapan KPS akan membantu siswa belajar mengembangkan pikirannya, memberi kesempatan kepada siswa untuk melakukan penemuan, meningkatkan daya ingat dan membantu siswa mempelajari konsep-konsep sains. Dalam penerapan KPS semua aspek harus dilatih dan diterapkan dengan struktural termasuk kegiatan mengklasifikasi suatu objek sehingga keseluruhan keterampilan ilmiah yang terarah baik kognitif dan psikomotorik yang dapat digunakan untuk menemukan suatu konsep atau prinsip atau teori untuk mengembangkan konsep yang telah ada sebelumnya ataupun untuk penyangkalan terhadap suatu penemuan.

\section{c. Komunikasi}

Untuk pertemuan pertama siklus I persentase siswa yang aktif terus mengalami kenaikan pada pertemuan pertama 25\% sedangkan persentase siswa yang aktif pada pertemuan kedua yaitu 39,07\%. Persentase yang meningkat dikarnakan siswa merasa antusias atau termotivasi atas model pembelajaran berbasis lingkungan dimana model pembelajaran ini membuat siswa merasa lebih leluasa dan memberikan kesempatan seluas-luasnya untuk ikut serta dalam kegiatan pembelajaran. Sedangkan pada siklus II pertemuan pertama persentase sebesar 40,73\% dan pada pertemuan kedua tidak mengalami peningkatan yang signifikan sehingga pesentase yang dicapai adalah 46,77 \% dengan demikian peningkatan persentase siswa yang aktif pada siklus I sebesar 6,04\%. Dengan demikian peningkatan rata-rata persentase siswa yang aktif dari siklus I ke siklus II sebesar 11,72\%. Hal ini terjadi karena materi-materi berikutnya merupakan materi yang berbeda dengan sebelumnya, dan guru harus selalu mengarahkan siswa untuk selalu memperhatikan penjelasan guru serta lebih teliti dalam melakukan pengamatan untuk dapat mengkomunikasikan hasil pengamatan dengan lengkap dan jelas. Dalam melakukan komunikasi siswa dituntut untuk dapat menyampaikan hasil pengamatannya secara individu yang disajikan dalam persentasi kelompok, siswa menyajikan hasil sesuai dengan apa yang didapat pada proses pengamatan yang di komunikasikan dengan perbendaharaan kata yang sesuai dalam bentuk gambar atau bagan untuk mencapai tujuan pembelajaran. Hal ini sesuai dengan pendapat Hamzah (2011:180) bahwa komunikasi yang efektif dalam pembelajaran mencakup penyajian yang jelas, kelancaran berbicara, interpretasi gagasan dengan contoh-contoh, kemampuan wicara yang baik dalam intonasi, nada, dan ekspresi.Guru terus memberikan motivasi kepada siswa untuk menerapkan keterampilan proses sains dalam melakukan komunikasi terutama dalam kegiatan diskusi dan presentasi dengan harapan aktivitas yang 
diinginkan akan mencapai indikator yang diharapkan.

\section{d. Mengajukan Pertanyaan}

Pertemuan pertama siklus I siswa yang aktif mengajukan pertanyaan sebesar 30\%, hal ini disebabkan ada beberapa siswa yang merasa takut dalam bertanya karna malu dan takut disalahkan oleh teman yang lain. Pada pertemuan kedua persentase siswa yang aktif meningkat menjadi 34,37\%. Dan rata-rata persentase siswa yang aktif sebesar 32\%. Persentase ini meningkat dibandingkan pada nilai pra PTK untuk mengajukan pertanyaan memiliki persentase $15 \%$ sehingga mengalami kenaikan 13,75\% pada siklus I. Untuk siklus II di pertemuan pertama persentase siswa yang mengajukan pertanyaan mengalami penurunan sebesar 33,33\%, Hal ini dikarenakan siswa mulai merasa percaya diri dalam mengajukan pertanyaan dikarnakan takut tidak sesuai dengan topik yang dibicarakan dan adanya anggapan bahwa yang bertanya memiliki arti siswa tersebut belum memahami atau tidak mengerti dengan materi yang diajarkan.

Peneliti mengatasi dengan jalan memotivasi siswa dengan mengungkapkan bahwa semua pertanyaan itu baik dan siswa yang bertanya bukan ciri orang yang kurang tetapi orang yang bertanya adalah bukti bahwa seseorang tersebut sedang berfikir tentang apa yang sedang diajarkan, yang tidak bertanya bukan berarti mengerti melainkan bisa sebaliknya. Pada pertanyaan yang bersifat mendidik, pertanyaan yang dijawab oleh siswa yang lain. Mereka menemukan sendiri jawaban yang terdapat upaya untuk memberikan pengrahan dengan bentuk isyarat untuk membimbing siswa menemukan jawabannya sampai kepada yang diharapkan.

Dalam penelitian ini siswa dituntut untuk mengungkapkan pertanyaan yang sesuai dengan topik atau materi pembelajaran, pertanyaan yang mudah ditandai oleh pertanyaan yang selalu berpusat pada tujuan dan materi pelajaran, ruang lingkup yang tidak terlalu luas, dan cukup menggambarkan keseluruhan materi pelajaran. Pertanyaan yang bermakna diungkapkan oleh Sagala (2008:205) bahwa pertanyaan bermakna adalah pertanyaan yang dapat membangkitkan aktivitas kegiatan pembelajaran, dapat membentuk pengetahuan, sikap, dan keterampilan yang dibutuhkan melalui kegiatan pembelajaran. Persentase siswa yang aktif mengajukan pertanyaan mengalami peningkatan dipertemuan kedua dengan persentase sebesar 35,48\%. Sehingga kenaikan persentase dari siklus I ke siklus II mencapai 12,41\%. Dengan adanya penekanan dan motivasi kenaikan persentase terus meningkat.

\section{e. Kesimpulan}

Pertemuan pertama siklus I persentase siswa yang membuat kesimpulan secara tertulis sebesar 76,66\%. Aktivitas ini terus mengalami peningkatan terus menerus dan sangat signifikan pada tiap pertemuanya pada siklus I dan siklus II. Pertemuan kedua siswa yang membuat kesimpulan meningkat menjadi $93,75 \%$, rat-rata persentase siswa aktif adalah 85,20\%.

Pada pertemuan pertama siklus II persentase siswa yang aktif mengalami peningkatan yang signifikan pada tiap pertemuan dari siklus I hingga siklus II. 
Pada siklus II pertemuan pertama dan pertemuan kedua persentase aktivitas membuat kesimpulan dalam bentuk tulisan memiliki persentase $81,48 \%$ dan 93,54\%, sehingga dari pertemuan pertama ke pertemuan kedua mengalami kenaikan 12,06\%. Dengan rata-rata kenaikan pada siklus II yaitu 87,51\%, peningkatan ini dikarnakan atas mulai terbiasanya siswa dalam menuliskan kesimpulan pada lembar kerja yang telah disediakan. Hal ini tidak lepas dari penekanan guru bahwa ketika melakukan pembelajaran siswa harus mengetahui tujuan dan dengan adanya tujuan maka perlu adanya kesimpulan. Penekanan dirasakan cukup memotivasi siswa untuk terbiasa dan mahir dalam membuat kesimpulan. Dengan demikian peningkatan persentase siswa yang aktif dari siklus I ke siklus II sebesar 2,31\%. Menutup pelajaran merupakan suatu kegiatan yang dilakukan guru untuk mengetahui pencapaian tujuan dan pemahaman peserta didik terhadap materi yang dipelajari, serta mengakhiri kegiatan pembelajaran salah satu kegiatan dalam menutup pelajaran yaitu menarik kesimpulan mengenai materi yang dipelajari dikemukakan Mulyasa (2008:84). Sehingga dengan meminta siswa untuk membuat kesimpulan maka guru akan mengetahui tingkat daya serap siswa yang telah didapat dalam kegiatan pembelajaran. Dari data peningkatan kelima KPS di atas dapat kita lihat bahwa menggunakan model pembelajaran berbasis lingkungan dapat meningkatkan siswa yang aktif terutama pada aktivitas mengajukan pertanyaan dan membuat kesimpulan.

\section{KESIMPULAN DAN SARAN}

\section{Kesimpulan}

Berdasarkan hasil penelitian dan pembahasan dalam penelitian ini dapat disimpulkan bahwa penerapan model pembelajaran berbasis lingkungan dapat meningkatkan keterampilan proses sains siswa kelas $\mathrm{X}_{2}$ genap SMA Negeri 2 Metro Tahun Pelajaran 2011/2012 pada materi Keanekaragaman Hayati yang ditunjukan oleh peningkatan presentase aktivitas KPS yang mendukung proses pembelajaran.

\section{Saran}

Berdasarkan kesimpulan tersebut peneliti menyarankan bahwa untuk meningkatkan keterampilan proses sains pada materi pokok Keanekaragaman Hayati dapat diterapkan pembelajaran berbasis lingkungan.

\section{DAFTAR RUJUKAN}

Ahmadi, Abu. 1995. Psikologi Belajar. Jakarta : Rineka Cipta.

.2004. Psikologi Belajar. Jakarta: Rineka Cipta.

Arikunto, Suharsini. 2006. Prosedur Penelitian. Jakarta: Rineka Cipta. . 2008. Penelitian Tindakan Kelas. Jakarta: Rineka Cipta.

Arsyad, Azhar. 2003. Media Pembelajaran. Jakarta: PT Raja Grafindo Persada

Barlian, Ikbal. 2010. Penelitian Tindakan Kelas (PTK). Palembang: Percetakan Universitas Sriwijaya. 
Dabutar, Jelarwin. 2010. Pengaruh Media Pembelajaran Terhadap Hasil Belajar Pengelasan Pada Siswa Yang Berprestasi Tinggi Dan Rendah Di Smk Swasta 1 Trisakti Laguboti-Kabupaten Toba Samosir. (Online).(http://smpn1 nainggolan.blogspot.com/2010/01/ pengaruh-media-pembelajaranterhadap.

html. Diakses 3 Juni 2011).

Hamalik, Oemar. 2007. Proses Belajar Mengajar. Jakarta : Bumi Aksara.

Hamzah. 2011. Belajar Dengan Pendekatan PAILKEM. Jakarta : Bumi Aksara.

Hendriani. 2004. Penggunaan Lingkungan Sebagai Sumber Belajar . Depdiknas: PPPG IPA.

Johariah. 2009. Upaya Meningkatkan Aktivitas dan Hasil Belajar Melalui Observasi Lingkungan Yang didesain sebagai Sumber Belajar Biologi pada Siswa SMK Negeri 1 Simpang Pematang. TP 2008/2009.Skripsi Tidak diterbitkan. Metro: Universitas Muhammadiyah Metro.

Karwono. 2010. Belajar dan Pembelajaran serta Pemanfaatan Sumber Belajar. Jakarta: Cerdas Jaya.

Trianto. 2010. Model Pembelajaran Terpadu. Jakarta: Bumi Aksara.

Wahyuningsih, Tri. 2010. Peningkatkan Aktivitas dan Hasil Belajar Siswa melalui Pemanfaatan Lingkungan sebagai Sumber
Belajar Biologi di SMP Negeri 3 Raman Utara. TP 2010/2011. Skripsi tidak diterbitkan. Metro: Universitas Muhammadiyah Metro. 